\title{
ANALISIS MANAJEMEN PENDEKATAN KELAS DALAM MENINGKATKAN KEDISIPLINAN PESERTA DIDIK SDN 002 SUNGAI PINANG
}

\author{
Samsul Adianto' ${ }^{1}$, Euis Kusumarini², Nurhayati ${ }^{3}$ \\ ${ }^{123}$ Universitas Widya Gama Mahakam Samarinda \\ E-mail: samsul4adianto@gmail.com
}

\begin{abstract}
This study aims to determine whether the application of Classroom Approach Management can improve the Discipline of Class VB Students at SDN 002 Sungai Pinang in 2020. This research was conducted at SDN 002 Sungai Pinang from April to July 2020. This re search design used a qualitative research design. The population of this study used students of class VB SDN 002 Sungai Pinang. The sampling technique used purposive sampling with the research subjects namely the teacher, the principal and four students. This study uses data collection techniques with interviews and documentation. The data analysis technique used was data collection, data reduction, data presentation and conclusion drawing. Checking the validity of the data using source triangulation techniques. Based on the results of research and interviews, it is known that there are ten approaches that are applied by teachers in the classroom in improving discipline. The teacher takes this approach in turn according to the classroom situation. However, of the ten applied app roaches that are more widely applied and have an influence in increasing student discipline, namely the power approach, for example, the imposition of sanctions, the freedom approach, for example, including students in making rules in class, teaching approaches.
\end{abstract}

Keywords: class approach management; discipline oflearners.

\begin{abstract}
ABSTRAK
Penelitian ini bertujuan untuk mengetahui apakah penerapan Manajemen Pendekatan Kelas dapat Meningkatkan Kedisiplinan Peserta Didik Kelas VB di SDN 002 Sungai Pinang Tahun 2020. Penelitian ini dilaksanakan di SDN 002 Sungai Pinang pada bulan April sampai Juli 2020. Desain penelitian ini menggunakan desain penelitian kualitatif. Populasi penelitian ini menggunakan peserta didik kelas VB SDN 002 Sungai Pinang. Teknik pengambilan sampel menggunakan purposive sampling dengan subjek penelitian yaitu guru, kepala sekolah dan empat orang peserta didik. Penelitian ini menggunakan teknik pengambilan data dengan wawancara dan dokumentasi. Teknik analisis data yang digunakan yaitu pengumpulan data, reduksi data, penyajian data dan penarikan kesimpulan. Pengecekan keabsahan data dengan menggunakan teknik triangulasi sumber. Berdasarkan hasil penelitian dan hasil wawancara diketahui bahwa terdapat sepuluh pendekatan yang diterapkan oleh guru di kelas dalam meningkatkan kedisiplinan. Guru menerapkan pendekatan tersebut secara bergantian sesuai dengan keadaan kelas. Namun dari sepuluh pendekatan yang diterapkan tersebut yang lebih banyak diterapkan dan memiliki pengaruh dalam meningkatkan kedisiplinan peserta didik yaitu pendekatan kekuasaan contohnya pemberian sanksi, pendekatan kebebasan contohnya mengikut sertakan peserta didik dalam pembuatan aturan di kelas, pendekatan pengajaran misalnya guru yang menjadi teladan dengan berperilaku yang baik, pendekatan perubahan tingkah laku.
\end{abstract}

Kata kunci: manajemen pendekatan kelas; kedisiplinan peserta didik.

Cara mengutip: Adianto, S., Kusumarini, E. \& Nurhayati. (2020). Analisis Manajemen Pendekatan Kelas dalam Meningkatkan Kedisiplinan Peserta Didik SDN 002 Pangkal Pinang. Inteligensi: Jurnal Ilmu Pendidikan, 3(2), 78-86 


\section{PENDAHULUAN}

Proses pembelajaran di sekolah merupakan suatu usaha yang dilaksanakan oleh guru dan peserta didik. Pada proses pengajaran akan terjadi intertaksi antara guru dengan peserta didik dan sesama peserta didik. Untuk itu, antara peserta didik dan guru dapat melakukan perannya masing-masing, guru memberikan pengajaran pada peserta didik bagaimana belajar. Saat ini sebagian besar sekolah menerapkan kurikulum 2013 dalam proses pembelajaran, dalam menjalankan proses belajar mengajar guru menerapkan beberapa inovasi dalam pembelajaran salah satunya pembelajaran kooperatif yang mana peserta didik belajar secara berkelompok untuk memecahkan suatu masalah dan menyatukan pendapat untuk mendapatkan hasil dari pemecahan masalah tersebut (Adianto, 2020a). Saat ini kurikulum yang berlaku menerapkan pembelajaran yang tidak hanya terfokuskan pada kepandaian tetapi juga dalam terbentuknya karakter yang mewajibkan guru melakukan penilaian secara autentik pada proses pembelajaran (Adianto et al., 2020).

Guru turut membentuk watak peserta didik dengan cara memberikan keteladanan dan penanaman nilai-nilai karakter kepada peserta didik meliputi komponen pengetahuan, kesadaran atau kemauan, dan tindakan untuk melaksanakan nilai-nilai tersebut (Sugiana, 2019). Supaya peserta didik bisa mengembangkan karakteristik tersebut dibutuhkannya dorongan dari berbagai sisi misalnya peserta didik itu sendiri. Peserta didik dapat membuat keadaan kelas menjadi lebih nyaman sehingga dapat berkonsentrasi dalam mengikuti kegiatan belajar mengajar di kelas. Suasana kelas yang kondusif tersebut telah mencerminkan karakter peserta didik dalam disiplin, hal tersebut merupakan langkah awal dalam pengembangan karakteristik dalam kurikulum 2013. Terwujudnya suasana kondusif tidak sertamerta timbul begitu saja, hal tersebut tidak lepas dari manajemen kelas yang guru terapkan dengan baik.

Manajemen kelas atau dengan istilah lain disebut juga pengelolaan kelas merupakan kemampuan guru dalam mengolah, menyusun dan mengorganisasi kelas agar terjadi suasana yang nyaman dan tertib. Guru yang profesional mampu memanajemen kelasnya dengan baik sehingga proses pembelajaran menjadi lebih efektif dengan suasana yang nyaman dan kondusif. Setiap peserta didik di ruang kelas memiliki sifat dan latar belakang yang berlainan, terdapat peserta didik yang begitu aktif dan peserta didik yang pendiam serta mempunyai kemampuan berfikir yang baik dan juga sebaliknya. Dengan kondisi peserta didik tersebut, maka menjadi tugas guru untuk menyatukan karakter peserta didik yang berbeda-beda agar memiliki sifat kedisipilan. Salah satunya guru dapat melakukan pendekatan di dalam kelas yang tepat untuk menghasilkan peserta didik yang memiliki nilai kedisiplinan tinggi.

Menurut Widiasworo (2018) pendekatan-pendekatan yang ada dapat digunakan sebagai penyesuaian kondisi serta situasi yang ada di dalam kelas. Penyesuaian kondisi dan situasi yang baik dapat memunculkan suasana yang kondusif dengan peserta didik yang tertib dan disiplin. Menurut Efendi (2020) manajemen pendekatan kelas adalah suatu 
solusi alternatif yang dapat digunakan oleh guru untuk membantu mengelola suatu kelas dengan baik. Adanya pendekatan kelas ini dapat membantu membuat kelas menjadi nyaman dan lebih kondusif, dengan itu tujuan pembelajaran akan dicapai secara maksimal. Pendekatan manajemen kelas merupakan suatu usaha guru dalam membangun suatu hubungan kerjasama dengan peserta didik dan guru dalam bentuk interaksi. Interaksi yang telah terjadi ini akan lebih optimal jika guru memilih pendekatan yang tepat dalam mengelola suatu ruang belajar supaya proses belajar mengajar menjadi lebih efektif. Selain efektifnya proses belajar mengajar, pendekatan yang dilakukan juga dapat meningkatkan kegairahan Proses belajar mengajar siswa baik secara individu maupun berkelompok. (Zahroh, 2015).

Kedisiplinan adalah suatu kekuatan yang menuntut peserta didik dalam menaati peraturan. Sikap disiplin mengajarkan peserta didik dalam memilih mana hal yang harus dilakukan, yang boleh dilakukan dan yang tidak boleh dilakukan. Kedisiplinan juga menjadi penilaian sikap dalam pembelajaran kurikulum 2013. Sikap disiplin yang dimiliki oleh peserta didik dapat mencerminkan karakter dari peserta didik itu sendiri. Menurut Arsyi (2018) disiplin adalah salah satu cara yang dilakukan pendidik agar bisa mengatur perilaku peserta didik dengan tegas dengan cara membuat aturan-aturan tata tertib di dalam ruangan maupun diluar ruangan kelas supaya dapat terbentuk sikap yang lebih baik. Menurut Imron (2011) kedisiplinan adalah sikap yang harus dimiliki oleh setiap peserta didik di sekolah. Peserta didik diharapkan dapat menjalani segala aturan dan tata tertib yang ada di sekolah dengan tidak melakukan pelanggaran yang dapat merugikan.

Menurut Kohlberg dalam Widodo (2013) kedisiplinan merupakan sikap kepatuhan yang tidak hanya terdapat pada norma-norma aturan yang berasal dari luar, namun juga terdapat pada kemampuan seseorang dalam mengendalikan diri. Kemampuan dalam mengendalikan diri dapat dimulai dengan menciptakan keteraturan serta ketertiban dalam kehidupan pribadi. Pengendalian diri dapat dijadikan dasar bagi setiap manusia dalam menghubungkan setiap pikiran, kebiasaan, emosi dan tingkah laku yang erat kaitannya dengan prinsip yang berlaku dimasyarakat sehingga terciptanya kedisiplinan yang mutlak. Penelitian oleh Rachman \& Agustian, 2016; Mahendra, 2017; Sa'adah et al, 2013 menyatakan bahwa penerapan pengelolaan kelas yang diterapkan oleh guru mampu meningkatkan kedisiplinan peserta didik, sehingga tujuan dari penelitian ini adalah untuk mengetahui pelaksanaan manajemen pendekatan kelas yang dilakukan oleh guru dalam meningkatkan kedisiplinan peserta didik kelas VB di SDN 002 Sungai Pinang.

\section{METODE PENELITIAN}

Penelitian ini menggunakan penelitian kualitatif menggunakan teknik purposive sampling. Subjek dalam penelitian ini adalah guru kelas VB, kepala sekolah dan 4 orang peserta didik. Instrumen utamanya berupa peneliti yang mengumpulkan informasi menggunakan pedoman observasi, pedoman wawancara dan dokumentasi. Wawancara digunakan sebagai pedoman peneliti untuk mendapatkan data tertentu yang berkaitan 
dengan masalah penelitian melalui kegiatan tanya jawab untuk mengumpulkan data penelitian (Arifin, 2017; Tersiana, 2018), dan dokumentasi berupa pedoman wawancara dan beberapa foto-foto kegiatan selama penelitian berlangsung (Yusuf, 2015).

Teknik analisis data yang digunakan mengadopsi teknik Miles dan Hubberman dalam Kurniawan (2018), disajikan dalam gambar 1 berikut:

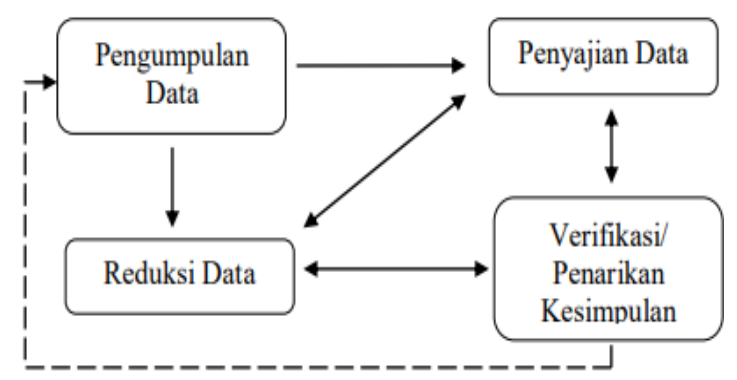

Gambar 1. Analisa Data

Peneliti melakukan pengecekan keabsahan data dengan menggunakan beberapa teknik yaitu wawancara dan dokumentasi.

\section{HASIL DAN PEMBAHASAN}

Bapak Jungkir selaku guru menyatakan bahwa pendekatan yang dapat digunankan dalam proses belajar dipilih dengan menyesuaikan keadaan yang terjadi di dalam kelas. Peserta didik juga dilibatkan dalam pembuatan aturan yang telah disepakati sebelumnya. Adanya pemberian reward dan hukuman dapat dijadikan sebagai motivasi peserta didik dalam meningkatkan kedisiplinan. Ibu Sriwati selaku kepala sekolah menyatakan bahwa keterampilan guru dalam menggabungkan beberapa pendekatan kelas dalam satu proses pembelajaran sudahh cukup terlihat, dengan keterampilan tersebut guru dapat berinteraksi dengan peserta didik sehingga mampu mendisiplinkan dan dapat mengetahui permasalahan yang membuat peserta didik menjadi kurang disiplin. Guru kelas juga selalu mengawasi peserta didik di dalam kelas, pembuatan aturan di dalam kelas juga melibatkan peserta didik. Pemberian hukuman dan reward dilakukan untuk membuat peserta didik menjadi lebih disiplin.

Hukuman juga dilakukan kepada peserta didik yang melakukan pelanggaran di kelas. pelanggaran yang sering dilakukan peserta didik yaitu terlambat kesekolah dan membolos. Setiap seminggu sekali dilakukan pengecekan kerapian dalam berpakaian, dalam proses pembelajaran guru selalu berada di dalam kelas untuk mengawasi peserta didik. Terkadang pemberian hadiah atau reward diberikan oleh guru kepada peserta didik yang disiplin. Terkadang pemberian hadiah atau reward diberikan oleh guru kepada peserta didik yang disiplin. Macam-macam manajemen pendekatan kelas yang diterapkan di kelas agar dapat meningkatkan kedisiplinan peserta didik yaitu:

a) Pendekatan kekuasaan merupakan suatu pendekatan yang digunakan oleh guru, berdasarakan hasil wawancara guru memberikan sanksi kepada peserta didik yang melakukan pelanggaran. Sanksi yang diberikan kepada peserta didik bermacammacam tergantung pelanggaran yang dilakukan. Sanksi dapat berupa teguran, peringatan, dan hukuman ringan untuk peserta didik yang melakukan pelanggaran ringan seperti membuat keributan di kelas, mengobrol ketika pembelajaran berlangsung, terlambat masuk kelas 
dan lain-lain. Pelanggaran yang tidak dapat ditolerir seperti membolos atau tidak hadir selama beberapa hari tanpa keterangan akan diberikan peringatan hingga diberikan surat panggilan kepada orang tua peserta didik yang juga diketahui oleh kepala sekolah.

b) Pendekatan intimidasi merupakan pendekatan yang jarang diterapkan oleh guru di kelas. Berdasarkan hasil wawancara bahwa peserta didik yang melakukan pelanggaran tidak pernah diberikan sanksi berupa hukuman fisik walaupun melakukan pelanggaran berat sekalipun. Peserta didik yang melakukan pelanggaran akan diberikan bimbingan oleh guru kelasnya. Tidak adanya ruang bimbingan khusus maka bimbingan dilaksanakan di dalam kelas pada saat jam istirahat.

c) Pendekatan kebebasan dengan pendekatan resep saling berkaitan, di kelas ketika guru membuat peraturan peserta didik ikut serta dalam menentukan aturan di dalam kelas melalui voting. Peraturan tersebut layak jika hasil voting telah disetujui oleh peserta didik. Peraturan yang telah disepakati oleh peserta didik harus ditaati karena peraturan dibuat dengan persetujuan peserta didik. Melibatkan peserta didik dalam pembuatan aturan agar peserta didik mengetahui hal-hal mana yang baik dan mana hal-hal yang kurang baik.

d) Penerapan pendekatan pengajaran di kelas dapat membuat guru menjadi teladan bagi peserta didik. Ketika mengajar di kelas guru selalu bertutur kata yang baik. Pendekatan ini dilakukan agar peserta didik dapat mencontoh apa yang mereka lihat dari gurunya. Guru dapat dijadikan teladan bagi peserta didik dalam membangun karakter kedisiplinan. Hal ini dikarenakan sikap kedisiplinan dimulai melalui tutur kata dan perilaku yang baik.

e) Pendekatan perubahan tingkah laku dan pendekatan sosio-emosional memiliki keterkaitan dalam penerapannya. Guru memberikan reward berupa pujian atau hadiah secara tidak langsung peserta didik akan merasa senang secara emosional dan akan berpengaruh terhadap tingkah lakunya. Pemberian reward ini merupakan salah satu cara guru untuk membangun hubungan yang positif antara peserta didik dan guru sehingga guru dapat mengawasi secara langsung proses perubahan tingkah laku peserta didik menjadi lebih baik. Hal ini membuat peserta didik dengan sendirinya akan melakukan perbuatan yang disiplin secara terus-menerus.

f) Pendekatan proses kelompok ini diterapkan supaya peserta didik dapat ikut dalam proses belajar mengajar dengan baik dan menyenangkan. Pendekatan ini di terapkan beberapa kali dalam suatu waktu ketika proses pembelajaran. Dalam pendekatan ini guru membuat beberapa kelompok dalam suatu pembelajaran agar peserta didik tidak merasa bosan dalam proses belajar mengajar di dalam kelas. Hal tersebut secara langsung dapat mengajarkan kepada peserta didik dalam bersosialisasi dan bekerja sama dalam suatu proyek. Pembuatan kelompok ini dirasa sudah cukup efektif dalam menarik perhatian peserta didik dalam mengikuti pembelajaran dengan antusias. 
Adanya kendala dari pembuatan kelompok ini yaitu sebagian kecil peserta didik yang masih menimbulkan keributan ketika pembelajaran di kelas yang mengganggu konsentrasi peserta didik.

g) Pendekatan elektis ini merupakan gabungan dari beberapa pendekatan yang diterapkan oleh guru. Pendekatan ini melatih kemampuan guru dalam memanajemen kelas dengan baik agar kelas menjadi kondusif dan proses pembelajaran berjalan dengan nyaman. Guru tidak dapat langsung mengetahui pendekatan mana saja yang dianggap cocok untuk diterapkan agar kelas menjadi kondusif dan nyaman. Guru mencoba menerapkan beberapa pendekatan yang dirasa cocok dengan keadaan kelas dan peserta didik, penerapan beberapa pendekatan akan dianggap cocok ketika tujuan pembelajaran berhasil dicapai dengan menggunakan pendekatan tersebut.

h) Pendekatan teknologi dan informasi pada saat pandemi covid-19 ini sangat berguna bagi guru dan peserta didik yang melakukan pembelajaran jarak jauh. Adanya teknologi ini dapat membuat peserta didik dan guru tetap bisa melakukan pembelajaran walaupun tidak bertatap muka. Sebelum adanya pandemi covid-19 ini pun peserta didik juga menggunakan teknologi dalam pembelajaran seperti mencari bahan ajar tambahan. Penggunaan teknologi ini juga diawasi oleh guru dan orang tua agar peserta didik tidak menyalahgunakan teknologi dengan menjurus ke hal-hal yang tidak baik. Hal tersebut mendapat respon yang baik dari orang tua maupun peserta didik karena sebagian besar peserta didik telah menggunakan gawai. Hal ini juga tidak lepas dari kendala yang dihadapi misalnya peserta didik yang tidak memiliki gawai membuatnya sulit mengikuti pembelajaran.

SDN 002 Sungai Pinang juga memiliki aturan yang berlaku seperti jam belajar di sekolah dan cara berpakaian yang wajib ditaati. Dalam aturan jam belajar yang berlaku peserta didik diwajibkan berada di kelas pada pukul 1 siang. Dari hasil wawancara, kebanyakan peserta didik telah disiplin terhadap aturan jam belajar yang telah disusun oleh sekolah sedangkan pada aturan cara berpakaian dari hasil wawancara guru mengatakan sebagian besar peserta didik telah mengikuti aturan berpakaian yang telah ditentukan oleh sekolah. Namun hanya sebagian kecil peserta didik yang masih saja melanggar aturan.

Membangun karakter peserta didik menjadi lebih baik merupakan tugas guru. banyak cara telah dilakukan oleh guru agar membuat peserta didik menjadi lebih disiplin misalnya pemberian reward. Pemberian reward ini terdapat berbagai macam misalnya dalam bentuk pujian, peserta didik yang berperilaku baik dan menunjukkan sikap disiplin akan diberikan reward dalam bentuk pujian sehingga peserta didik merasa diberikan apresiasi dalam perbuatannya dan dapat menguatkan sikap disiplinnya di dalam kelas (Adianto, 2020b). Jika peserta didik yang melakukan pelanggaran akan diberikan hukuman berupa sanksi. Sanksi yang diberikan pun bermacam-macam tergantung pelanggaran apa yang dilakukan peserta didik, sanksi tersebut berupa membersihkan kelas, 
diberikan tugas lebih hingga panggilan kepada orang tua peserta didik.

Hal tersebut tidak lepas dari hambatan-hambatan yang ditemui oleh guru. Berdasarkan hasil wawancara terdapat beberapa faktor yang membuat peserta didik menjadi tidak disiplin yaitu faktor lingkungan, faktor keluarga dan dari dalam diri peserta didik sendiri. Faktor lingkungan terdapat dari pengaruh temantemannya di sekolah maupun di rumah, sedangkan faktor keluarga karena pengaruh orang tua yang berpisah dan kurangnya perhatian orang tua terhadap peserta didik. Kemauan peserta didik sendiri adalah suatu motivasi yang sangat penting dalam menanamkan sikap disiplin karena peserta didik secara sukarela menjalankan kedisiplinan tersebut tanpa adanya paksaan. Hal senada disampaikan oleh (Adianto, 2018), motivasi yang muncul dalam diri siswa akan membuat siswa melakukan hal-hal yang baik. Pada hasil penelitian dan pembahasan di atas penerapan pendekatan kekuasaan dan pendekatan ancaman atau intimidasi oleh guru dapat membuat peserta didik mendapatkan efek jera terhadap peserta didik yang melakukan pelanggaran sehingga tidak mengulangi pelanggaran yang dilakukan. Penerapan pendekatan kebebasan dan pendekatan resep juga diterapkan oleh guru dalam pembuatan aturan di kelas yang bermaksud untuk memberi tahu peserta didik akan hal-hal yang baik dan yang tidak baik untuk dilakukan. Penerapan pendekatan pengajaran juga diterapkan karena guru dapat memberikan contoh teladan bagi peserta didik dalam hal berperilaku baik dan disiplin. Pendekatan perubahan tingkah laku dan pendekatan sosioemosional juga diterapkan oleh guru merupakan bentuk kerjasama antara guru dan peserta didik dalam meningkatkan kedisiplinan dengan membangun hubungan yang positif dan pemberian reward. Pendekatan proses kelompok diterapkan juga oleh guru untuk menarik perhatian peserta didik dalam pembelajaran di kelas. Pendekatan elektis diterapkan oleh guru untuk mengetahui pendekatan yang cocok dalam pendisiplinan peserta didik. Pendekatan teknologi dan informasi sebelumnya jarang diterapkan oleh guru, namun saat ini pendekatan teknologi ini diterapkan untuk proses pembelajaran jarak jauh.

SDN 002 Sungai Pinang juga sudah melakanakan aturan dengan baik oleh guru maupun peserta didik. Terkhusus di kelas VB sebagian besar peserta didik telah menunjukkan sikap disiplinnya. Upaya telah dikerahkan oleh guru untuk membangun karakter peserta didik dengan memberikan reward dan hukuman. Keberhasilan mengelola juga dipengaruhi keberhasilan guru dalam membangun komunikasi yang baik antar guru dan murid, jika setiap masalah dapat dikomunikasikan maka masalah seberat apa pun dapat diselesaikan (Adianto, 2019).

\section{SIMPULAN}

Penerapan pendekatan yang dilaksanakan oleh guru untuk meningkatkan kedisiplinan sudah cukup baik, terdapat 10 pendekatan yang digunakan oleh guru yaitu, pendekatan kekuasaan, pendekatan ancaman atau intimidasi, pendekatan kebebasan, pendekatan resep, pendekatan pengajaran, pendekatan perubahan tingkah laku, pendekatan sosio-emosional, pendekatan elektis dan pendekatan teknologi dan 
informasi. Namun dari 10 pendekatan yang diterapkan tersebut pendekatan kekuasaan, pendekatan kebebasan, pendekatan pengajaran, pendekatan perubahan tingkah laku dan pendekatan elektis yang paling sering diterapkan dan memiliki pengaruh dalam meningkatkan kedisiplinan peserta didik, disusul dengan pendekatan yang lainnya. Upaya lain juga telah dikerahkan oleh guru untuk membangun karakter disiplin peserta didik dengan memberi reward dan hukuman. Banyak faktor yang menjadi penghambat kedisiplinan peserta didik seperti faktor keluarga, faktor lingkungan dan faktor dari dalam diri peserta didik.

\section{DAFTAR PUSTAKA}

Adianto, S. (2018). Increased Activity, Motivation And Learning Outcomes Mathematics With Learning Model Cooperative Type Numbered Head Together In Grade III Students. IJECA: International Journal of Education \& Curriculum Application, 1(3), 35-38. Http s://Doi.Org/Https://Doi.Org/10.3 1764/Ijeca.V133.2123

Adianto, S. (2019). Peningkatan Komunikasi Dan Hasil Belajar Matematika Melalui Model Pembelajaran Kooperatif Think Pair Share Pada Siswa Kelas III SDN 003 Sungai Kunjang. PENDAS MAHAKAM: Jurnal Pendidikan Dasar, 3(3), 200-210. Https://Doi.Org/Jurnal.Fkip-

Uwgm.Ac.Id/Index.Php/Pendasmaha $\mathrm{kam} /$ Article/View/248

Adianto, S. (2020a). Penerapan Scientific Dan Cooperative Learning Dengan Quis Online Untuk Meningkatkan Hasil Belajar Siswa Sekolah Dasar. JINOTEP (Jurnal Inovasi Teknologi Pembelajaran), 7(1), 57-65. Https://Doi.Org/Http://Dx.Doi.Org/1

\subsection{7/Um031v7i12020p057}

Adianto, S. (2020b). Peningkatan Motivasi Dan Hasil Belajar Matematika Tentang Pecahan Melalui Model Find The Fib Pada Siswa Sekolah Dasar. SIKOLA: Jurnal Kajian Pendidikan Dan Pembelajaran, 2(2), 116-125.

Https://Doi.Org/Https://Doi.Org/10.2 4036/Sikola.V2i2.83

Adianto, S., Ikhsan, M., \& Oye, S. (2020). Penilaian Autentik Pada Kurikulum 2013 Dalam Pembelajaran Tematik Sekolah Dasar. JINOTEP (Jurnal Inovasi Teknologi Pembelajaran), $7(2)$, 133-142. Https ://Doi.Org/10.17977/Um031v7i 22020p133

Arifin, Z. (2017). Evalusi Pembelajaran. PT. Remaja Rosdakarya.

Arsyi, M. (2018). Motivasi Beprestasi \& Disiplin Peserta Didik Serta Hubungannya Dengan Hasil Belajar. Yudha English Gallery.

Efendi, R. (2020). Manajemen Kelas Di Sekolah Dasar. Qiara Media.

Imron, A. (2011). Manajemen Peserta Didik. Bumi Aksara.

Kurniawan, A. (2018). Metodologi Penelitian Pendidikan. PT. Remaja Rosdakarya.

Mahendra, F. (2017). Analisis Manajemen Kelas Dalam Proses Pembelajaran Tematik Kelas IV SD Negeri. Jurnal Pendidikan.

Rachman, A., \& Agustian, M. (2016). Meningkatkan Kedisiplinan Siswa Melalui Pengelolaan Kelas Di SDN 23 Pagi Palmerah Jakart. Jurnal Perkotaan, 8(2), 75-93. Https://Doi.Org/10.25170/Perkotaan. V8i2.277

Sa'adah, A., Maisyaroh, \& Supriyanto, A. (2013). Hubungan Pendekatan Manajemen Kelas Dengan Motivasi Belajar Siswa. Jurnal Manajemen Pendidikan, 24(2).

Sugiana, A. (2019). PENANAMAN NILAI KARAKTER DISIPLIN 
DAN TANGGUNG JAWAB DI

SMK ETHIKA PALEMBANG. PAI

Raden Fatah, 1(1), 105-116.

Tersiana, A. (2018). Metodologi Penelitian. Stat Up.

Widiasworo, E. (2018). Cerdas Pengelolaan Kelas. Diva Press.

Widodo, B. (2013). Perilaku Disiplin Siswa Ditinjau dari Aspek Pengendalian Diri (Self control) dan Keterbukaan Diri (Self Disclosure) pada Siswa SMK Wonosari Caruban Kabupataen Mediun. Jurnal Widya Warta, 1(37), 140-151.

Yusuf, M. (2015). Asesmen dan Evaluasi Pendidikan. Prenda Media Group.

Zahroh, L. (2015). Pendekatan Dalam Pengelolaan Kelas. Tasyri', 22, 175189. 